\title{
HUBUNGAN ANTARA STATUS SOSIAL EKONOMI DENGAN STATUS GIZI BALITA DI KELURAHAN BUHA KECAMATAN MAPANGET KOTA MANADO
}

\author{
Nancy Lidya Sampouw \\ Fakultas Keperawatan Universitas Klabat, Jalan Arnold Mononutu, \\ Airmadidi, Minahasa Utara 95371, Indonesia \\ E-mail: nancy.sampouw@unklab.ac.id
}

\begin{abstract}
ABSTRAK
Anak usia di bawah lima tahun (balita) merupakan "usia emas" dalam pertumbuhan dan perkembangan. Balita merupakan kelompok umur yang paling sering menderita kekurangan gizi. Balita yang kekurangan gizi dapat disebabkan oleh faktor sosial ekonomi keluarga. Status sosial ekonomi sebagai akar dari kekurangan gizi yang berhubungan dengan daya beli pangan di rumah tangga sehingga berdampak terhadap pemenuhan zat gizi. Tujuan penelitian yaitu untuk mengetahui hubungan antara status sosial ekonomi dengan status gizi balita di Kelurahan Buha Kecamatan Mapanget Kota Manado. Metode penelitian yaitu analitik dengan pendekatan cross sectional. Sampel yang digunakan sebanyak 71 balita dengan menggunakan teknik purposive sampling. Proses pengumpulan data menggunakan kuesioner dan diuji statistik dengan rumus prosentase untuk menjawab pernyataan pertama dan kedua, uji Spearmen Correlation untuk menjawab pernyataan ketiga. Hasil penelitian ditemukan bahwa gambaran status sosial ekonomi yaitu pendapatan rendah, gambaran status gizi balita yaitu gizi lebih dan tidak ada hubungan yang signifikan antara status sosial ekonomi dengan status gizi balita dengan nilai $\mathrm{p}=0,60>0,05$. Dapat disimpulkan bahwa tidak ada hubungan yang signifikan antara status sosial ekonomi dengan status gizi balita di Kelurahan Buha Kecamatan Mapanget Kota Manado. Rekomendasi untuk peneliti selanjutnya untuk menambahkan variabel yang lain yaitu faktor yang mempengaruhi status gizi balita yaitu hygiene sanitasi lingkungan dimana keadaan lingkungan yang kurang baik memungkinkan terjadinya berbagai penyakit antara lain penyakit kekurangan gizi bahkan gizi buruk.
\end{abstract}

Kata Kunci: Status Gizi Balita, Status Sosial Ekonomi.

\begin{abstract}
Children under five years of age (toddlers) are a "golden age' in growth and development. Toddlerd are the age group most often suffering from malnutrition. Undernourished toddlers can be caused by family socio-economic factors. Socio-economis status is the root of the fulfillment of nutrients. The research objective was to determine the relationship between socioeconomic status and nutritional status of children under five in Buha Village, Mapanget District, Manado City. The research method is analytic with cross sectional approach. The sample used was 71 toddlers using purposive sampling technique. The process of collecting data using a questionnaire and statistically tested with percentage formula to answer the first and second statements, the Spearmen Correlation test to answer the third statement. The results showed that the description of socioeconomic status was low income, nutritional status of children under five was over nutrition and there was no significant relationship between socioeconomic status and nutritional status of children under five with a value of $p=0.60>0.05$. It can be concluded that there is no significant relationship between socioeconomic status and nutritional sattus of children under five in Buha Village, Mapanget District, Manado City. Recommendation for
\end{abstract}


further reseachers to add other variables namely the factors that effect the nutritional status of toddlers, namely environmental sanitation hygiene where the environmental conditions are not good enough to allow various diseases including malnutrition.

Keywords: Nutritional Status of Toddlers, Socioeconomics Status.

\section{PENDAHULUAN}

Anak usia di bawah lima tahun (balita) merupakan "usia emas" dalam pertumbuhan dan perkembangan. Menurut Kementerian Kesehatan Republik Indonesia (Kemenkes RI, 2019), balita atau anak usia 0-5 tahun merupakan periode emas dalam pertumbuhan dan perkembangan yang harus mendapat asupan gizi yang adekuat. Usia 05 tahun merupakan kelompok usia yang penting dalam pertumbuhan dan perkembangan untuk sumberdaya manusia dari segi pertumbuhan fisik dan kecerdasan (IDAI, 2019).

Balita merupakan kelompok umur yang paling sering menderita kekurangan gizi. Menurut Hartono (2017), balita 0-5 tahun merupakan kelompok umur di masyarakat yang sering menderita kekurangan gizi atau termasuk salah satu kelompok masyarakat yang rentan gizi kurang. Simamora (2014), anak usia 0-5 tahun merupakan golongan yang paling rawan kekurangan gizi, sedangkan pada usia ini merupakan periode penting pemenuhan gizi untuk pertumbuhan dan perkembangan.

World Health Organization (WHO) tahun 2015 melaporkan bahwa prevalensi kurang gizi pada anak 0-5 tahun di dunia sekitar $14,3 \%$ dengan jumlah anak yang mengalami kekurusan sebanyak 95,2 juta anak (WHO, 2015). Hasil Riset Kesehatan Dasar tahun 2018 menunjukkan bahwa Indonesia masih memiliki masalah kekurangan gizi dengan prevalensi kekurangan gizi (underweight) 19,6\% (Riskedas, 2018). Jumlah kasus kekurangan gizi di Provinsi Sulawesi Utara tahun 2018 sebanyak 49 kasus dari jumlah pertumbuhan anak di Sulawesi Utara (Bagian Data, Depkes Sulawesi Utara, 2019). Berdasarkan data laporan tahunan Dinas Kesehatan Kota Manado melalui program gizi tahun 2018 di Kecamatan Mapanget diketahui status gizi kurang sebanyak 227 anak dan gizi buruk sebanyak 3 anak (Sub Bagian Gizi Masyarakat, Dinkes Kota Manado, 2019).

Balita usia 0-5 tahun dengan gizi kurang dapat mengakibatkan terganggunya pertumbuhan sel otak yang mempengaruhi kecerdasan anak. Gizi kurang atau buruk pada anak terutama usia kurang dari lima tahun dapat mengakibatkan terganggunya pertumbuhan sel otak yang mempengaruhi kecerdasan anak, di mana pertumbuhan sel otak sangat cepat dan akan mencapai sempurna pada usia 4-5 tahun, dan perkembangan otak hanya dapat dicapai bila anak berstatus gizi baik (Octaviani \& Margawati, 2012). Anak balita yang mengalami kekurangan gizi akibat asupan gizi yang kurang dapat mempengaruhi pertumbuhan sel otak anak dan kecerdasan anak yang dapat mempengaruhi sumber daya manusia (Simamora, 2014).

Status gizi anak dipengaruhi oleh beberapa faktor langsung dan factor tidak langsung. WHO tahun 1997 menyatakan bahwa status gizi anak dipengaruhi oleh faktor langsung yaitu ditentukan oleh asupan makanan dan penyakit infeksi, sedangkan faktor tidak langsung meliputi ketahanan pangan dalam keluarga yang dipengaruhi oleh pendapatan dalam keluarga, dan pengetahuan ibu akan gizi anak yang dipengaruhi oleh latar belakang pendidikan ibu. Menurut Indarti (2016), faktor-faktor tidak langsung tidak terlepas dari karakteristik keluarga, di mana karakteristik keluarga dapat mempengaruhi status gizi anak.

Penelitian yang dilakukan oleh Indarti (2016), menunjukkan bahwa ada hubungan antara satus sosial ekonomi dengan status gizi balita di Kecamatan Ajung Kabupaten Jember Tahun 2016. Hal yang sama dengan penelitian yang dilakukan oleh Simbolon (2016), menunjukan bahwa ada hubungan antara status sosial ekonomi 
dengan status gizi anak balita di Desa Nifuboke, Nusa Tenggara Timur (NTT) tahun 2016. Momuat, Kandou dan Malonda (2017), menyatakan bahwa ada hubungan antara status sosial ekonomi dengan status gizi balita di Desa Tatelu Kecamatan Dimembe Kabupaten Minahasa Utara Tahun 2017.

Hasil survei awal yang dilakukan peneliti melalui wawancara dan observasi di Kelurahan Buha, bahwa ada beberapa warga yang memiliki status sosial ekonomi rendah serta status gizi anak yang kurang. Berdasarkan uraian latar belakang serta beberapa hasil penelitian terdahulu dan survei awal yang telah dilakukan, maka peneliti tertarik untuk melakukan penelitian dengan judul "Hubungan Antara Status Sosial Ekonomi Dengan Status Gizi Balita di Kelurahan Buha Kecamatan Mapanget Kota Manado"

\section{METODE}

Metode penelitian ini menggunakan observasional analitik dengan desain penelitian cross sectional yaitu cara pengambil data variabel independen dan dependen dilakukan sekali waktu secara bersamaan (Sarwono, 2006). Sampel dalam penelitian ini yaitu anak laki-laki dan perempuan berusia 0-5 tahun yang bertempat tinggal di Kelurahan Buha Kecamatan Mapanget Kota Manado yang berjumlah 71 orang. Pengambilan sampel dalam penelitian ini menggunakan rancangan non probability sampling, dengan teknik pengambilan sampel yaitu purposive sampling ialah cara menentukan sampel menggunakan kriteria sesuai tujuan peneliti (Sugiyono, 2016). Penentuan besar sampel pada penelitian ini dengan jumlah populasi yang tidak diketahui untuk penelitian cross sectional didasarkan pada teori Lemeshow.

$$
\text { Instrumen penelitian yang }
$$

digunakan dalam penelitian ini yaitu alat penimbang berat badan yang bermerek one med dan alat tulis menulis yaitu pena dan kertas. Alat ukur dalam penelitian ini berupa kuesioner yang digunakan untuk mengumpulkan data secara formal kepada subjek untuk menjawab pertanyaan secara tertulis. Kuesioner yang digunakan untuk penelitian ini terdiri dari tiga bagian yaitu, bagian pertama untuk informed consent, bagian kedua untuk identitas responden (anak) dan identitas orangtua responden, serta bagian ketiga untuk mengkaji status sosial ekonomi keluarga dan status gizi balita. Mengukur status sosial ekonomi yaitu pendapatan keluarga berdasarkan penghasilan orangtua (suami dan istri) dalam satu bulan yang dinilai menurut Upah Minimum Provinsi (UMP) Sulawesi Utara Tahun 2019 sesuai dengan Peraturan Gubernur Sulawesi Utara Nomor 433 Tahun 2018 (Idris, 2018) yaitu Rp 3.051.076,00. Skala yang digunakan yaitu skala ordinal (tinggi skor satu dan rendah skor nol), tinggi jika pendapatan keluarga $>$ RP. 3.051.076,00 dan rendah jika $\leq \mathrm{Rp}$ 3.051.076,00. Untuk mengidentifikasi status gizi balita menggunakan kurva $z$-score BMIfor-age WHO untuk usia 0-5 tahun dan dikategorikan menggunakan indeks $\mathrm{BB} / \mathrm{U}$ baku rujukan WHO-NCHS (IDAI, 2019). Berat badan diukur sebanyak tiga kali kemudian diambil rata-rata berat badan dalam satuan kilogram. Gizi buruk jika zscore $<-3,0 \mathrm{SD}$; gizi kurang $z$-score -3,0 SD $\mathrm{s} / \mathrm{d}<-2,0 \mathrm{SD}$; gizi baik z-score $-2,0 \mathrm{SD}$ s/d 2,0 SD; dan gizi lebih z-score > 2,0 SD.

Penelitian dilakukan di Kelurahan Buha Kecamatan Mapanget Kota Manado, dengan ibu yang memiliki anak usia 2-5 tahun. Pengambilan data dilakukan pada selama bulan November sampai Desember 2019. Pengambilan data status sosial ekonomi dengan cara memberikan kuesioner dan orangtua responden mengisi pilihan pendapatan keluarga tinggi jika pendapatan keluarga > RP. 3.051.076,00 dan rendah jika $\leq \mathrm{Rp}$ 3.051.076,00. Pengambilan data status gizi balita berupa pengukuran berat badan per umur dengan mengikuti panduan status gizi balita menggunakan kurva z-score BMIfor-age WHO.

Dalam melakukan sebuah penelitian harus mempertimbangkan suatu etika guna menghormati harkat kemanusian, privasi dan hak dari responden. Etika dalam penelitian ini yaitu responden bersedia berpartisipasi dalam penelitian tanpa ada paksaan dengan menandatangani informed consent yang sebelumnya peneliti telah menjelaskan tujuan dan prosedur yang akan dilakukan. Responden dilindungi hakhaknya dengan hanya menyertakan inisial dalam lembar penelitian dan diberi 
kebebasan dalam mengisi kuesioner sesuai dengan kondisi yang dialami.

Data diolah secara deskriptif melalui analisis univariat dengan distribusi prosentase, kemudian analisis bivariat menggunakan rurmus statistik Spearman Correlation dengan media aplikasi Software Statistical Product and Service Solution (SPSS).

\section{HASIL}

Pada bagian ini akan membahas mengenai hasil analisis data penelitian dengan interpretasi data yang sudah diolah dengan program statistik untuk menjawab tujuan penelitian.

\section{Gambaran status sosial ekonomi}

Hasil analisis status sosial ekonomi di Kelurahan Buha Kecamatan Mapanget Kota Manado, diperoleh hasil seperti pada Tabel 1.

\section{Tabel 1. Gambaran Status Sosial} Ekonomi

\begin{tabular}{lccc}
\hline $\begin{array}{c}\text { Status } \\
\text { Sosial } \\
\text { Ekonomi }\end{array}$ & $\begin{array}{c}\text { Freque } \\
\text { ncy }\end{array}$ & Percent & $\begin{array}{c}\text { Cumulative } \\
\text { Percent }\end{array}$ \\
\hline Tinggi & 31 & 43.7 & 56.3 \\
Rendah & 40 & 56.3 & 100.0 \\
Total & 71 & 100.0 & \\
\hline
\end{tabular}

Tabel 1 menunjukkan gambaran status sosial ekonomi di Kelurahan Buha Kecamatan Mapanget Kota Manado yang didapat dari total sampel 71 responden. Dari hasil didapati 31 responden $(43,7 \%)$ keluarga pendapatan tinggi dan 40 responden $(56,3 \%)$ keluarga pendapatan rendah. Data tersebut menunjukan bahwa gambaran status sosial ekonomi di Kelurahan Buha Kecamatan Mapanget Kota Manado yaitu pendapatan rendah.

\section{Gambaran status gizi balita}

Hasil analisis status gizi balita di Kelurahan Buha Kecamatan Mapanget Kota Manado, diperoleh hasil seperti pada Tabel 2.
Tabel 2. Gambaran Status Gizi Balita

\begin{tabular}{lccc}
\hline $\begin{array}{c}\text { Status } \\
\text { Gizi } \\
\text { Balita }\end{array}$ & Frequency & Percent & $\begin{array}{c}\text { Cumulative } \\
\text { Percent }\end{array}$ \\
\hline Lebih & 38 & 53.5 & 53.5 \\
Baik & 20 & 28.2 & 81.7 \\
Kurang & 7 & 9.9 & 91.5 \\
Buruk & 6 & 8.5 & 100.0 \\
Total & 71 & 100.0 & \\
\hline
\end{tabular}

Tabel 2 menunjukkan gambaran status gizi balita di Kelurahan Buha Kecamatan Mapanget Kota Manado yang didapat dari total sampel 71 responden. Dari hasil didapati 38 responden $(53,5 \%)$ balita memiliki status gizi lebih, 20 responden $(28,2 \%)$ balita memiliki status gizi baik, 7 responden $(9,9 \%)$ balita memiliki status gizi kurang, 6 responden $(8,5 \%)$ balita memiliki status gizi buruk. Data tersebut menunjukan bahwa gambaran status gizi balita di Kelurahan Buha Kecamatan Mapanget Kota Manado yaitu gizi lebih.

Hubungan antara status sosial ekonomi dengan status gizi balita

Hasil analisis hubungan status sosial ekonomi dengan status gizi balita di Kelurahan Buha Kecamatan Mapanget Kota Manado, diperoleh hasil seperti pada Tabel 3.

Tabel 3. Hubungan Status Sosial Ekonomi Dengan Status Gizi Balita

\begin{tabular}{|c|c|c|c|}
\hline $\begin{array}{c}\text { Variabe } \\
1\end{array}$ & & $\begin{array}{c}\text { Status } \\
\text { Sosial } \\
\text { Ekono } \\
\text { mi } \\
\end{array}$ & $\begin{array}{c}\text { Status } \\
\text { Gizi Balita }\end{array}$ \\
\hline \multirow{3}{*}{$\begin{array}{l}\text { Status } \\
\text { sosial } \\
\text { ekono } \\
\text { mi }\end{array}$} & $\begin{array}{l}\text { Correlation } \\
\text { Coefficient }\end{array}$ & 1.00 & -.06 \\
\hline & $\begin{array}{l}\text { Sig. (2- } \\
\text { tailed) }\end{array}$ & . & .60 \\
\hline & $\mathrm{N}$ & 71 & 71 \\
\hline \multirow{3}{*}{$\begin{array}{l}\text { Status } \\
\text { gizi } \\
\text { balita }\end{array}$} & $\begin{array}{l}\text { Correlation } \\
\text { Coefficient }\end{array}$ & -.06 & 1.00 \\
\hline & $\begin{array}{l}\text { Sig. (2- } \\
\text { tailed) }\end{array}$ & .60 & . \\
\hline & $\mathrm{N}$ & 71 & 71 \\
\hline
\end{tabular}


Berdasarkan data pada Tabel 3, hasil uji statistik Spearmen Correlation hubungan antara status sosial ekonomi dengan status gizi balita didapati hasil nilai $p$-value $=0.60>0.05$, dengan demikian $\mathrm{H}_{0} 1$ gagal ditolak. Kesimpulannya, tidak ada hubungan yang signifikan antara status sosial ekonomi dengan status gizi balita di Kelurahan Buha Kecamatan Mapanget Kota Manado.

\section{DISKUSI}

Hasil penelitian menunjukkan bahwa gambaran status sosial ekonomi di Kelurahan Buha Kecamatan Mapanget Kota Manado yang didapat dari total sampel 71 responden, terdapat 40 responden $(56,3 \%)$ keluarga pendapatan rendah. Berdasarkan Upah Minimum Provinsi (UMP) Sulawesi Utara Tahun 2019 (Peraturan Gubernur Sulawesi Utara Nomor 433 Tahun 2018) pendapatan rendah artinya $\leq \mathrm{Rp}$ 3.051.076,00. Menurut Bunaen, Wahongan, dan Onibala (2013), tingkat pendapatan yang tergolong rendah menjadi akar permasalahan dari ketidakmampuan keluarga untuk menyediakan pangan dalam jumlah, mutu, dan ragam yang sesuai dengan kebutuhan setiap individu untuk memenuhi asupan zat gizi yang bermanfaat bagi pertumbuhan, kesehatan, dan daya tahan jasmani maupun rohani. Status sosial ekonomi rendah di Kelurahan Buha Kecamatan Mapanget Kota Manado yaitu pendapatan keluarga dibawah UMP dan hal ini dapat menyebabkan akar permasalahan dari ketidakmampuan keluarga untuk menyediakan pangan dalam jumlah, mutu, dan ragam yang sesuai dengan kebutuhan setiap individu untuk memenuhi asupan zat gizi.

Pada gambaran status gizi anak di Kelurahan Buha Kecamatan Mapanget Kota Manado, hasil penelitian menunjukkan bahwa dari total sampel 71 responden terdapat 38 responden $(53,5 \%)$ anak memiliki status gizi lebih. Menurut Mardalena (2017), gizi lebih artinya keadaan gizi seseorang di mana jumlah energi dan protein yang masuk lebih besar dari jumlah yang dibutuhkan. Asupan energi dan protein yang berlebih dapat menyebabkan status gizi lebih berdasarkan indeks berat badan per umur (Mann \&
Truswell, 2014). Penelitian ini sejalan dengan penelitian yang dilakukan oleh Bunaen, Wahongan, dan Onibala, (2013), didapati bahwa kelebihan gizi khususnya jumlah kalori dan protein berpengaruh terhadap kadar vitamin dan mineral yang menjadi faktor risiko timbulnya masalah gizi yang mengidentifikasi gangguan status gizi. Status gizi anak lebih di Kelurahan Buha Kecamatan Mapanget Kota Manado akibat jumlah energi dan protein yang masuk lebih besar dari jumlah yang dibutuhkan yang dapat menyebabkan masalah gizi yang bisa menimbulkan penyakit yaitu obesitas.

Hasil penelitian menunjukkan bahwa hubungan status sosial ekonomi dengan status gizi anak di Kelurahan Buha Kecamatan Mapanget Kota Manado didapati bahwa tidak ada hubungan yang signifikan antara status sosial ekonomi dengan status gizi anak. Menurut Arisman (2007), pendapatan keluarga berpengaruh terhadap status gizi individu dan keluarga oleh karena pendapatan menentukan ketersediaan pangan baik secara kuantitas maupun kualitas. Penelitian ini sejalan dengan penelitian yang dilakukan oleh Rumende, Kapantow dan Punuh (2016) didapati bahwa tidak ada hubungan antara status sosial ekonomi dengan status gizi anak balita di Kabupaten Timor Tengah Utara, Provinsi Nusa Tenggara Timur Tahun 2016 dengan nilai $\mathrm{p}=0,38>0,05$. Berdasarkan hasil penelitian di atas dapat disimpulkan bahwa meskipun status sosial ekonomi rendah tetapi status gizi anak lebih karena orangtua memperhatikan kebutuhan gizi untuk setiap anggota keluarga terutama kebutuhan gizi anak khususnya memperhatikan kebutuhan gizi anak usia balita. Adapun beberapa faktor yang didapati peneliti yang menyebabkan anak dengan status gizi lebih yaitu orang tua sering membawa anak ke posyandu yang diadakan setiap minggu pada hari rabu. Posyandu menyediakan makanan yang cukup gizi seperti bubur kacang hijau kemasan, telur, dan susu. Sesuai informasi dari kepala puskesmas bahwa program pemerintah untuk pemenuhan gizi anak di puskesmas yaitu Pemberian Makanan Tambahan (PMT) untuk balita. PMT merupakan kegiatan pemberian makanan kepada balita dalam bentuk makanan yang aman dan bermutu dengan memperhatikan aspek mutu dan keamanan pangan. Balita 
yang datang ke Posyandu akan memperoleh PMT selama seminggu kedepan untuk pemenuhan gizi balita selama semingu sampai kembali datang ke Posyandu minggu berikutnya. Dapat disimpulkan bahwa tidak ada hubungan antara status sosial ekonomi dengan status gizi anak di Kelurahan Buha Kecamatan Mapanget Kota Manado, yang mana status sosial ekonomi keluarga dengan pendapatan rendah, tapi status gizi balita dengan gizi lebih karena balita mendapat PMT dari posyandu setiap minggunya.

\section{KESIMPULAN DAN REKOMENDASI}

Gambaran status sosial ekonomi dalam kategori rendah. Gambaran status gizi anak dalam kategori gizi lebih. Tidak ada hubungan yang signifikan antara status sosial ekonomi dengan status gizi anak di Kelurahan Buha Kecamatan Mapanget Kota Manado.

Hasil dari penelitian ini diharapkan dapat memberi informasi kepada masyarakat untuk memperhatikan status gizi anak sekalipun status sosial ekonomi keluarga rendah dengan mengikuti kegiatan posyandu serta memperhatikan status gizi anak jangan sampai menyebabkan penyakit obesitas. Rekomendasi untuk peneliti selanjutnya untuk menambahkan variabel yang lain yaitu faktor yang mempengaruhi status gizi anak yaitu hygiene sanitasi lingkungan dimana keadaan lingkungan yang kurang baik memungkinkan terjadinya berbagai penyakit antara lain penyakit kekurangan gizi bahkan gizi buruk.

\section{REFERENSI}

Arisman. (2007). Gizi Dalam Daur Kehidupan. Jakarta: EGC Buku KedokteranS.

Bunaen, Wahongan, \& Onibala. (2013). Hubungan Sosial Ekonomi Keluarga Dengan Status Gizi Pada Anak Usia Pra Sekolah 3-5 Tahun di Taman Kanak-Kanak GMIM Baithani Koha. Jurnal Keperawatan, 09-2014. Retrieved July 12, 2019, from https://www.ejurnal.com/2014/11/hubungan-sosialekonomi-keluarga-dengan.html

Handini, D. (2013). Hubungan Tingkat
Pendapatan Keluarga Dengan Status

Gizi Balita di Wilayah Kerja

Puskesmas Kalijambe. Jurnal

Universitas Muhamadiyah Surakarta, 20404-09. Retrieved July 12, 2019, from http://eprints.ums.ac.id/24014/9/naskah _publikasi.pdf

IDAI. (2019). Kurva Pertumbuhan WHO. Retrieved July 12, 2019, from https://www.idai.or.id/downloads/WH $\mathrm{O} / 2 . \mathrm{BB} \% 20$ menurut\%20usia/Lakilaki/0_5\%20tahun.pdf dan https://www.idai.or.id/downloads/WH $\mathrm{O} / 2 . \mathrm{BB} \% 20$ menurut\%20usia/Perempu an/0_5\%20tahun.pdf

Idris, M. (2018). Gubernur Olly Tetapkan UMP 2019 Sulut Rp 3.051.076.

Retrieved July 12, 2019, from https://news.detik.com/berita/d4283543/gubernur-olly-tetapkan-ump2019-sulut-rp-3051076

Kemenkes RI. (2019). Pedoman Gizi Seimbang (Nutritional Guidelines). Retrieved July 12, 2019, from https://linisehat.com/downloadpedoman-gizi-seimbang-kementeriankesehatan/

Mann, J., Truswell, S. (2014). Buku Ajar Ilmu Gizi. Jakarta: EGC.

Mardalena, I. (2017). Dasar-dasar Ilmu Gizi Dalam Keperawatan. Yogyakarta: Pustaka Baru Press.

Momuat, T., \& Kandou, G., (2017). Hubungan Antara Status Sosial Ekonomi Dengan Status Gizi Balita Di Desa Tatelu Kecamatan Dimembe Kabupaten Minahasa Utara. Jurnal Kesehatan Masyarakat, 6 (3).

Myrnawati \& Anita, M. (2016). Pola Makan Terhadap Status Gizi Anak (Studi Kausal Di Pos Paud Kota Semarang Tahun 2015 ). Pendidikan Usia Dini, $10(8), 1-20$.

Nursalam. (2008). Metodologi Penelitian Ilmu Keperawatan. Jakarta: Penerbit Salemba Medika, 978-979.

Oktavia, S., Widajanti, L., \& Aruben, R. (2017). Faktor-Faktor Yang Berhubungan Dengan Status Gizi Buruk Pada Balita Di Kota Semarang Tahun 2017 (Studi Di Rumah 
Pemulihan Gizi Banyumanik Kota Semarang). Jurnal Kesehatan Masyarakat (E-Journal), 5(3), 186192. Retrieved July 12, 2019, from https://Ejournal3.Undip.Ac.Id/Index.Ph p/Jkm/Article/View/17209/16470

Riyadi, H., Martianto, D., Hastuti, D., Damayanthi, E., \& Murtilaksono, K. (2011). Faktor-Faktor Yang Mempengaruhi Status Gizi Anak Balita di Kabupaten Timor Tengah Utara, Provinsi Nusa Tenggara Timur. Jurnal Gizi Dan Pangan, 6 (1), 66. Retrieved July $\quad 12, \quad 2019, \quad$ from Https://Doi.Org/10.25182/Jgp.2011.6.1. 66-73

Riskesdas. (2018). Prevalensi Kekurangan Gizi. Retrieved July 12, 2019, from https://drive.google.com/file/d/1 Vpf3nt FMm3A78S8Xlan2MHxbQhqyMV5i/v iew

Rumende, M., Kapantow, N. H., Punuh, P. I., (2016). Hubungan Antara Status Sosial Ekonomi Dengan Status Gizi Pada Anak Usia 24-59 Bulan di Kecamatan Tombatu Uatara Kabupaten Minahasa Tenggara. Jurnal KESMAS, Volume 7 Nomor 4. Retrieved July 12, 2019, from https://ejournal.unsrat.ac.id/index.php/k esmas/article/view/23157+\&cd=1\&hl= en\&ct=clnk\&gl=id

Sarwono, J (2006). Metode Penelitian Kuantitatif dan Kualitatif. Yogyakarta: Graha Ilmu.

Sebataraja, L. R., Oenzil, F., \& Asterina. (2014). Hubungan Status Gizi Dengan Status Sosial Ekonomi Keluarga Murid Sekolah Dasar Di Daerah Pusat Dan Pinggiran Kota Padang. Jurnal Kesehatan Andalas, 3(2), 182-187.

Sugiyono, (2016). Metode Penelitian.

Yogyakarta: Alfabeta.

Syamsudin, Astuti, W. T., Setyono, E. (2016). Sosial Ekonomi Keluarga Dengan Status Gizi Balita. Retrieved July 12, 2019, from https://www.ejurnal.com/2016/11/sosial-ekonomikeluarga-dengan-status.html

WHO. (2015). UNICEF-WHO-The World

Bank Joint Child Malnutrition
Estimates. Retrieved July 12, 2019, from

https://www.who.int/nutgrowthdb/jme_ unicef_who_wb.pdf?ua=1 